DOI: https://doi.org/10.32839/2304-5809/2021-5-93-71

УДК 331.215 .24

Литвак Д.С., Величко Л.А.

Дніпровський національний університет імені Олеся Гончара

\title{
УПРАВЛІННЯ РОЗВИТКОМ ЕКОНОМІКИ ПІДПРИЕМСТВ БУДІВЕЛЬНОЇ ГАЛУЗІ
}

\begin{abstract}
Анотація. Стаття присвячена дослідженню проблеми забезпечення економічного розвитку будівельних підприемств в Україні. Визначено тенденції розвитку даної галузі економіки, вплив зовнішніх та внутрішніх факторів на збутову діяльність підприемств. Також проведено оцінку господарської діяльності двох успішних будівельних підприемств Дніпропетровського регіону. З’ясовано переваги та недоліки будівельних компаній. Встановлено, що головними напрямами підвищення збутової діяльності є активізація маркетингової діяльності підприемств будівництва в Україні. Також розроблено основні заходи, що дозволять підвищити попит і пропозицію на надання будівельних послуг на прикладі досліджуваних підприемств. В ході дослідження було запропоновано здійснити такі маркетингові заходи: PR-методи; доповнити асортимент послугами з більш дешевої вітчизняної сировини (наприклад, декоративна шпаклівка, натяжна стеля і т.д.). Визначили, що важливим завданням, яке стоїть перед будь-якою фірмою, $є$ формування індивідуального фрірмового стилю, що забезпечить ідентифікацію компанії на ринку.
\end{abstract}

Ключові слова: збутова діяльність, будівництво, економіка, будівельна компанія, підприемство, маркетингові заходи.

Lytvak Darya, Velychko Lyudmila

Oles Honchar Dnipro National University

\section{MANAGEMENT OF ECONOMIC DEVELOPMENT OF CONSTRUCTION INDUSTRY ENTERPRISES}

Summary. Improving the efficiency of Ukrainian enterprises is one of the most important tasks of both the state (reproduction of such conditions that would ensure the continuous operation of the enterprise) and the main task of managers of enterprises (analysis, generation and implementation of measures to improve production efficiency based on achievements scientific and technological progress and best practices of other enterprises). The inevitable globalization of the world economy increases the importance of the problem of economic development efficiency. The construction industry is a complex set of interactions of processes within which there is a constant development of construction companies and their integration. As a result, there is a thorough complication of relations between participants in the economic market of the construction industry. The main task of this area is the commissioning of new, as well as the reconstruction, expansion or repair of existing facilities for industrial or non-industrial purposes. Like any industry, construction has a number of features that distinguish it from others. Namely, it is the nature of the final product, specific working conditions, the specifics of the application of equipment, technology; organization of production, etc. All this creates a specific demand for products and services of the enterprise, because it provides the primary human needs. The dynamism and unpredictability of the external environment, as well as the deteriorating economic situation in Ukraine in recent years have negatively affected the functioning of domestic producers. In such conditions, the construction business faces the task of organizing an effective production and marketing process at the enterprise, accompanied by new management approaches. Businesses that do not want to be outsiders in the market must constantly monitor changes in the external and internal environment, and in critical situations to take preventive measures. Therefore, marketing management is gaining more and more popularity in the construction business among business entities. Therefore, there is a need to choose the right marketing tools, which depends on the characteristics of the external environment of the enterprise and its capabilities. The chosen strategy of the enterprise must coincide with the strategy of marketing and, consequently, advertising. Targeted actions are best directed towards maximizing the total current profit of the construction company.

Keywords: business activity, business, economics, commercial enterprise, enterprise, marketing

Постановка проблеми. Сучасне мінливе середовище визначає важливість пошуку підприемствами способів інтенсивного розвитку, що забезпечить їм високий рівень збутової політики.

В таких умовах перед будівельним бізнесом постає завдання організації ефективного виробничо-збутового процесу на підприемстві, супроводжуючи його новими підходами управління. Підприемства, які не бажають бути аутсайдерами на ринку, мають постійно моніторити зміни зовнішнього та внутрішнього середовища, а у критичних ситуаціях здійснювати превентивні заходи.

Аналіз останніх досліджень та публікацій. Вагомий внесок у дослідження поняття «збутової активності» та «маркетингової активізації» будівельних компаній, аналіз конкурентних переваг, вплив зовнішніх і внутрішніх чинників на економічний розвиток підприемств, а також розробку стратегій його покращення зробили саме вітчизняні науковці. Проблема правильного вибору стратегії управління економічним розвитком підприемства є досить важливою для їі розв'язання. Завдяки дослідженням та розробкам українських науковців за даною темою існує безліч теоретичних матеріалів для того, щоб почерпнути їх для застосування на власному підприемстві. Найбільше привертають увагу роботи таких вчених: Р.В. Козак, Є.В. Мних, П.Ю. Буряк, А.І. Рибак, П.С. Рогожин, Т.Ф. Скрябінська, О.А. Підлісна та ін. 
Виділення невирішених раніше частин загальної проблеми. Під час виконання роботи були поставлені і вирішені такі завдання:

- досліджено теоретичні основи управління економічним розвитком підприємств будівельної промисловості;

- здійснено аналіз особливостей економічного розвитку будівельних підприемств;

- запропоновано підвищення едективності виробничо-збутової діяльності будівельних підприемств на основі використання маркетингових інструментів.

- надано рекомендації щодо економічного розвитку будівельного підприемства шляхом аналізу витрат та застосування методу економії бюджету.

Мета статті. Метою даної статті є розробка комплексу заходів задля підвищення швидкості економічного розвитку підприемства галузі будівництва в Україні. Для досягнення поставленої мети необхідно вирішити наступні завдання: дослідити теоретичні основи управління економічним розвитком підприемств будівельної промисловості; здійснити аналіз особливостей економічного розвитку будівельних підприемств; запропонувати підвищення ефективності виробничо-збутової діяльності будівельних підприемств на основі використання маркетингових інструментів; надати рекомендації щодо економічного розвитку будівельного підприемства шляхом аналізу витрат та застосування методу економії бюджету.

Тож все більших обертів популярності у веденні будівельного бізнесу серед суб'єктів господарювання набирає саме маркетингове управління. Отже, виникае необхідність у виборі правильних маркетингових інструментів, що залежить від особливостей зовнішнього оточення підприемства та його можливостей. Особливо гостро постає проблема перспектив розвитку будівельної галузі, оскільки вона $е$ важливим елементом розвитку економічного стану України.

Виклад основного матеріалу. Будівництво виступае головною ланкою будівельного комплексу країни. Він складаеться з чотирьох великих блоків: виробництво матеріалів, власне будівництво, будівельне машинобудування, проектно-конструкторські та дослідні роботи в галузі [5]. Будівництво має особливі ознаки, що відрізняють його від інших галузей, а саме: кінцевий товар- будівлі, споруди. Вони е нерухомими, великогабаритними, створюючи при цьому більшість основних виробничих і невиробничих фондів. Будівельна галузь не може існувати як самостійна, адже тісно пов'язана з іншими.

В Україні будівельні підприемства розглядаються як сукупність економічних, інвестиційних та інтелектуальних потенціалів підприемства. Використання цих складових забезпечуеться за рахунок інвестування в основний, оборотний та людський капітал задля досягнення економічного ефректу.

У 2017 році будівництво в Україні було на підйомі свого розвитку, отримуючи стабільні показники протягом всього року. Вартість виконаних робіт за звітний період становила 101,1 млрд грн. В порівнянні з попереднім роком об'єми робіт зросли на $21 \%$. При дослідженні причин тако- го успіху було виявлено, що на процес вплинула низка прийнятих законодавчих змін у рамках дерегуляції будівництва, що безпосередньо вплинуло на розвиток галузі. Одним із найсерйозніших об’ектів в 2017 році став «захисний контур» комплексу захисних споруд на Чорнобильській $\mathrm{AEC}$, завершення якого тривало 7 років [6].

У 2018 році продовжилось зростання попереднього року, при цьому вартість виконаних робіт досягла розміру більш, як 136 млрд грн. Цього року було змінено 27 ДБН, що своїми постановами забороняють хаотичну забудову міст.

За підсумками 2018 року підприемства України виконали будівельні роботи на суму 136,3 млрд грн, індекс будівельної продукції по відношенню до 2017 року склав 104,4\%.

У 2019 році у порівнянні з попереднім роком теж відбулося зростання виробництва будівельної продукції на 20,8\%. Нове будівництво, реконструкція та технічне переоснащення становило $75,5 \%$ від загального обсягу виконаних робіт [5].

У 2020 році нове будівництво склало $49,7 \%$ від загального обсягу виробленої продукції, капітальний і поточний ремонти - $25,3 \%$, реконструкція та технічне переооснащення - 25,0\% [3].

Тож дивлячись на динаміку розвитку будівельної галузі в Україні можна дійти висновку, що це досить перспективний вид господарської діяльності. 3 кожним роком нові технології та техніка дозволяють все швидше доводити проекти до завершення, що безпосередньо впливає на розміри їх прибутковості.

У науковій літературі вчені визначають головним елементом аналізу стану будівельної галузі саме основний капітал. Це відбувається через те, що мета фонкціонування даної сфери полягає у формуванні і відтворенні основного капіталу. Всі інфраструктурні елементи сфери, як об’екти, так і суб'єкти, присутні в усіх галузях національної економіки, тому функціонування будь-якого елементу потребуе обов'язкових відтворювальних заходів, а саме це: ремонти, модернізація, реконструкщія, первинне будівництво.

Процес будівництва являе собою багатофункціональну систему, елементи в якій пов'язані великою кількістю зв'язків та залежностей. Звертаючи увагу на зарубіжний досвід ведення будівельної діяльності стае відомо, що розміри асигнувань в дану галузь становить від 20 до 25 відсотків бюджетних коштів. Що стосуеться України, то ми маємо показник 13-15 відсотків. Щоб проаналізувати інтенсивність впливу будівництва на добробут громадян, треба звернутись до даних про кількість квадратних метрів житлової площі, що припадає на 1 людину. Наприклад, в Норвегії на одного жителя припадає $140 \mathrm{~m}^{2}$, в США - $50 \mathrm{~m}^{2}$, в Україні - $17 \mathrm{~m}^{2}$.

У зв'язку з переходом від адміністративнопланової до ринкової системи відбулися зміни у цілях виробництва (тепер це отримання максимального прибутку), змінилися форми власності, керівники набули повної самостійності в прийняттях управлінських рішень, утворилися нові форми товару та вільний ринок. Саме тому виникла необхідність у розвитку маркетингу підприємств [8]. Маркетингову діяльність визначають як систему дій, основною ціллю яких е управління виробничо-збутовою діяльністю підприемств 
за рахунок дослідження та аналізу ринку фрункціонування підприемств та задоволення потреб споживачів в максимальних обсягах. Вона полягає в перетворенні постійно змінюваних потреб людей у додаткові вигоди організації. Керівництву будівельного підприємства може здаватися, що їхні можливості обмежені, але це лише нездатність побачити свої сильні сторони [7].

У будь-якого підприемства на кожному етапі його розвитку існує безліч ринкових перспектив. Проте знайти можливості та визначити серед них необхідні для власного підприємства є складним завданням. Для того, щоб обрати ідеї, які відповідають ресурсам і цілям підприємства, необхідно пройти процес, що складаеться з чотирьох етапів:

1. Заміри і прогнозування попиту.

2. Сегментування ринку.

3. Відбір щільових сегментів ринку.

4. Позиціонування товару на ринку.

Не менш важливими заходами при плануванні маркетингових дій є визначення мети рекламування, вибір засобів та носіїв реклами [4]. Важливі питання, які необхідно визначити для успішної організації просування компанії: обрати макет реклами, колір звернення, визначити частоту появи рекламного звернення та аудиторію, яку було заплановано охопити [9].

Для визначення бюджету рекламування на будівельному підприємстві обирається найпростіший і найбільш доцільний метод. Він полягає у визначенні приросту обсягів надання послуг даної групи, що плануеться в наступному періоді. За цим методом підприемство виділяе спочатку кошти на всі елементи маркетингових заходів, окрім комунікацій. Залишкові кошти i будуть становити бюджет рекламування [2]. Даний метод має свої переваги і недоліки, представлені у таблиці (табл. 1).

Таким чином будь-яке підприємство будівельної галузі може збільшувати або зменшувати витрати на комунікації в наступному періоді на той чи інший відсоток, опираючись на розмір асигнувань поточного періоду. Це досить зручний підхід до планування бюджету, оскільки береться до уваги приріст об'єму продажів та тенденції щодо асигнувань на рекламу, що існували в попередньому періоді [1].

Таблиця 1

Переваги та недоліки методу 3 визначення приросту обсягів наданих послуг

\begin{tabular}{|c|c|}
\hline Переваги & Недоліки \\
\hline $\begin{array}{c}\text { Наявність вихідної точки } \\
\text { розрахунків }\end{array}$ & $\begin{array}{l}\text { Відсутність зв'язку } \\
\text { витрат на рекламу } \\
\text { зі стратегією фірми }\end{array}$ \\
\hline $\begin{array}{c}\text { Побудова бюджету на минулих } \\
\text { успіхах підприємства } \\
\text { та майбутніх тенденціях }\end{array}$ & $\begin{array}{c}\text { Небезпека лишитися } \\
\text { без коштів } \\
\text { на рекламу }\end{array}$ \\
\hline Зручність розрахунків & \\
\hline
\end{tabular}

Таким чином будь-яке підприемство будівельної галузі може збільшувати або зменшувати витрати на комунікації в наступному періоді на той чи інший відсоток, опираючись на розмір асигнувань поточного періоду. Це досить зручний підхід до планування бюджету, оскільки береться до уваги приріст об'єму продажів та тенденщї щодо асигнувань на рекламу, що існували в попередньому періоді [1].

На сучасному етапі вітчизняний будівельний ринок є достатньо насичений будівельними компаніями, тобто можливості нарощування обсягів продажу за рахунок збільшення виробничих потужностей - майже вичерпані. Така ситуація спонукає виробників до активної взаємодії зі споживачами за допомогою маркетингових інструментів. Значення маркетингової діяльності та їі цільової спрямованості на будівельних підприємствах доведемо, використавши модель "Айсбергу» маркетингу [2] (рис. 1).

3 данного рисунку видно, що маркетингові комунікації впливають на невелике коло споживачів. Проте непряма реклама від задоволених споживачів охопить все більшу аудиторію (ïx родичів, друзів, колег тощо). Останні ж також поширюватимуть інформацію про компанію своїм знайомим, і так буде продовжуватись по ланцюгу. Тож з боку підприемства потрібно підтримувати дану ситуащію за допомогою всіх можливих маркетингових інструментів, при цьому не втрачаючи якість перед потенційними замовниками.

Тож такий важливий процес, як маркетингові комунікації, необхідний для створення позитивного образу будівельної компанії, адже незначна кількість споживачів (верхівка айсбергу) може збільшити чисельність споживачів в рази (нижня частина айсбергу).

Також важливо врахувати і протилежну дію мультиплікативного ефекту, тобто можливість втрати певної частки споживачів внаслідок невдоволення декількох осіб наданими послугами. Згідно 3 цим принципом 10 невдоволених клієнтів можуть розповісти про невдалий досвід 3 будівельною компанією своїм 5 знайомим. Таким чином кількість потенщійно втрачених клієнтів вже складатиме 50 осіб. В такому випадку необхідно якнайшвидше зреагувати, визначити тенденції розвитку будівельного ринку, адже набагато складніше для компанії повернути втрачених споживачів, ніж отримати існуючих.

Процес створення бренду - це складний процес, який не має єдиної методології. Проте існують певні принципи задля успішного брендового розвитку. В першу чергу якість наданих послуг мають завжди відповідати бажанням клієнта. Жодна реклама не змусить клієнта звернутись до компанії знову, якщо попереднього разу він не отримав якісної послуги. По-друге, у компанії має бути і емоційна складова, що буде апелювати до життевих цінностей цільової групи. По-трете, у реалізації концепції бренду головне - послідовність.

Найбільший вплив на економічну результативність має саме ціна, якість обслуговування та репутація компанії. Не менш важливими фракторами є управління відносинами з клієнтами та стимулювання збуту. I на останньому місці по відсотковому впливу на економічні результати для даних компаній є PR, реклама та місцерозташування об'єкту та офрісу. Хоча за впливом ці фрактори не в лідерах, проте вони дають змогу заявити компанії про себе та привернути увагу клієнтів, які вже потім розглянуть і ціну, і якість, і репутацію компанії. 


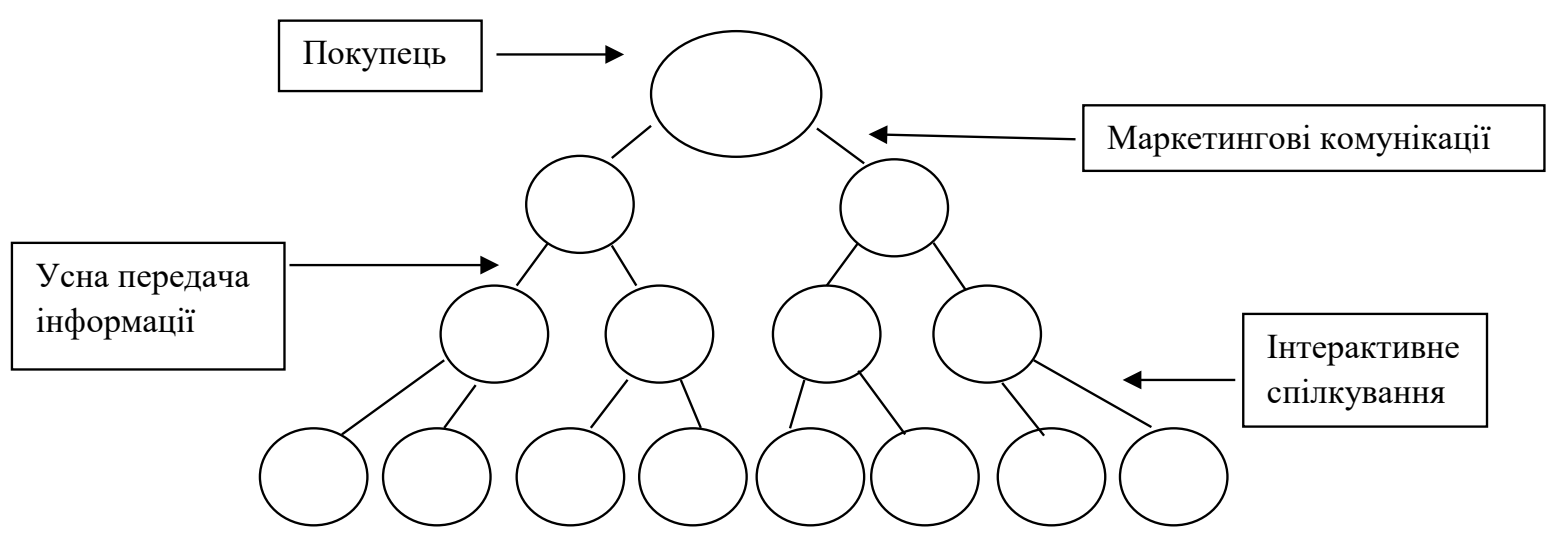

Рис. 1. Модель «Айсбергу» маркетингу

Джерело: розроблено авторами за даними [4]

Будівельним підприемствам важливо також враховувати сезонність попиту на окремі види послуг. Аналіз динаміки реалізації будівельних послуг по місяцях показав, що пік продажів робіт та послуг припадає на весну та літо, що пов'язано зі сприятливими погодними умовами, а в перші місяці року відбувається зменшення обсягів реалізацї, оскільки при мінусовій температурі повітря порушується технологія використання деяких матеріалів.

Також було виявлено основні проблеми у зовнішньому середовищі підприемств будівельних послуг. Вони пов'язані зі зростанням цін на сировину; зниженням рівня доходів більшості споживачів; ризиками експортної діяльності; залежністю від дистриб'юторів та насиченістю ринку.

Також всім будівельним компаніям при плануванні збутової діяльності та підвищенні їі едективності необхідно здійснювати оптимізацію витрат на маркетингову діяльність на основі фрункціональної залежності фрінансових результатів (виручка, валовий та чистий прибуток) від рівня витрат на маркетингові заходи.

Висновки та пропозиції. Будівництво виступає головною ланкою будівельного комплексу країни. Будівництво має особливі ознаки, що відрізняють його від інших галузей, а саме: кінцевий товар - будівлі, споруди. Вони є нерухомими, великогабаритними, створюючи при цьому більшість основних виробничих і невиробничих фрондів. Будівельна галузь не може існувати як самостійна, адже тісно пов'язана з іншими. В Україні будівельні підприемства розглядаються як сукупність економічних, інвестиційних та інтелектуальних потенціалів підприемства.

Для будівельної 3 метою підвищення ефективності збутової діяльності було запропоновано здійснити такі маркетингові заходи: PR-методи; доповнити асортимент послугами 3 більш дешевої вітчизняної сировини (наприклад, декоративна шпаклівка, натяжна стеля і т.д.). Важливим завданням, яке стоїть перед будь-якою фрірмою, $\epsilon$ форомування індивідуального фрірмового стилю, що забезпечить ідентифікацію компанії на ринку.

Також кожна будівельна компанія повинна проводити активну рекламну компанію, щоб залишитись на теперішньому рівні, або ж зростати, використовуючи як традиційні маркетингові рекламні канали, так і нові перспективні.

\section{Список літератури:}

1. Альошина. І.В. Поведінка споживачів : навч. посіб. для вузів. Москва, 1999. 384 с.

2. Блудова Т.В. Оптимізація маркетингових витрат фірми. Вчені записки : збірник наукових праць. Київ, 2009. № 11. C. $167-174$.

3. Боровик Ю.Т. Стійкий розвиток будівельного підприемства - важлива умова забезпечення конкурентоспроможності транспортного будівельного комплексу. Вісник еконоліки транспорту $i$ пролисловості. Харків, 2018. № 62. C. 151-157.

4. Васін Ю.В. Едективні програми лояльності. Як залучити й утримати клієнтів. Москва, 2006. С. 152.

5. Голубков Є.П. Основи маркетингу : підручник. Москва, 2003. 688 с.

6. Грищенко Ї.М. Маркетингові основи комерційного посередництва. Вчені записки : збірник наукових праць. Київ, 2006. № 9. 303 с.

7. Довгань Л.Є., Каракаш Ю.А. Управління стійким розвитком підприемства в умовах турбулентного середовища. Економічний потениіал сталого розвитку країни: сучасний стан, тендениї̈ та проблели відтворення : збірник наукових праць Міжнар. наук.-практ. конф. Львів. С. 95.

8. Кен Бланшар. Як домогтися лояльності кліентів в серері послуг : підручник. Москва, 2008. 208 с.

9. Кулібанова В.В. Маркетинг сервісних послуг : підручник. 2006. 192 с.

10. Малик І.П., Каракаш Ю.А. Основні інструменти для забезпечення стійкого розвитку підприемства. Сучасні підходи до управління підприемствол : збірник технічних доповідей. Київ, 2018. С. 99.

\section{References:}

1. Aloshyna I.V. (1999) Povedinka spozhyvachiv [Consumer behavior]. Ukrainian Economic Journal, p. 384.

2. Bludova T.V. (2009) Optymizaciya marketyngovyx vytrat firmy [Optimization of marketing costs of the firm]. Scientific notes: a collection of scientific papers, vol. 11, pp. 167-174.

3. Borovy`k Y.T. (2018) Stijkyj rozvytok budivelnogo pidpryyemstva - vazhlyva umova zabezpechennya konkurentospromozhnosti transportnogo budivelnogo kompleksu [Sustainable development of a construction enterprise is an 
important condition for ensuring the competitiveness of the transport construction complex]. Bulletin of Transport Economics and Industry, vol. 62, no. 10, pp. 151-157.

4. Vasin Y.V. (2006) Efektyvni programy loyalnosti. Yak zaluchyty j utrymaty kliyentiv [Effective loyalty programs. How to attract and retain customers], p. 152.

5. Golubkov Y.P. (2003) Osnovy marketyngu [Fundamentals of marketing]. Moscow, p. 688.

6. Gryshhenko Y.M .(2006) Marketyngovi osnovy komercijnogo poserednycztva [Marketing basics of commercial intermediation]. Scientific notes: a collection of scientific papers, vol. 9, p. 303.

7. Dovgan L.Y., Karakash Y.A. Upravlinnya stijkym rozvytkom pidpryyemstva v umovax turbulentnogo seredovyshha [Management of sustainable development of the enterprise in a turbulent environment]. Proceedings of the suchasnyj stan, tendenciyi ta problemy vidtvorennya: zbirnyk naukovyx pracz Mizhnar. nauk.-prakt. konf. Lviv, p. 95.

8. Ken Blanshar (2008) Yak domogtysya loyalnosti kliyentiv v sferi poslug [How to achieve customer loyalty in the field of services]. Moscow, p. 208.

9. Kulibanova V.V. (2006) Marketyng servisnyx poslug [Marketing services], p. 192

10. Malyk I.P., Karakash Y.A. (2018) Osnovni instrumenty dlya zabezpechennya stijkogo rozvytku pidpryyemstva. Suchasni pidxodydo upravlinnya pidpryyemstvom [The main tools for sustainable development of the enterprise. Modern approaches to enterprise management: a collection of technical reports]. Proceedings of the $z b i r n y k$ texnichnyx dopovidej (Ukraine), Kyiv, p. 99. 